\title{
PENGARUH HOSPITALISASI TERHADAP TINGKAT KECEMASAN ANAK PRESCHOOL DI RUMAH SAKIT TK II PUTRI HIJAU KESDAM I/BB MEDAN
}

\author{
The Effect of Hospitalization on the Level of Anxiety of Preschool Children \\ in Putri Hijau Hospital Kesdam I/BB Medan
}

\author{
Ade Irma Khairani ${ }^{1}$, Nina Olivia ${ }^{2}$ \\ ${ }^{1,2}$ Dosen Tetap Yayasan Akademi Keperawatan Kesdam I/BB Medan \\ Email : manurungade@gmail.com
}

\begin{abstract}
Abstrak
Anak yang sakit memiliki respon yang berbeda dimana anak memiliki kecemasan yang tidak biasa dengan berinteraksi dengan orang lain, hal tersebut menyebabkan anak harus menjalani rawat inap. Di Indonesia diperkirakan 35\% anak-anak yang menjalani rawat inap dan $45 \%$ mengalami kecemasan. Tujuan penelitian ini adalah untuk mengetahui pengaruh hospitalisasi terhadap tingkat kecemasan anak prasekolah pada anak rawat inap di rumah sakit TK II Putri Hijau Kesdam I/BB Medan. Jenis penelitian ini adalah survei analitik dengan desain cross sectional. Populasi dalam penelitian ini di seluruh anakanak prasekolah yang dirawat di TK II Putri Hijau Kesdam I/BB Medan dengan rata-rata jumlah bulanan 35 pasien. Sampel yang digunakan sebanyak 20 orang menggunakan teknik total sampling. Data diperoleh menggunakan kuesioner dan dianalisis dengan menggunakan Spearman Rank Test (Rho). Hasil pengujian Spearman Rank (Rho) dengan hasil yang diperoleh $\alpha=0,05 \mathrm{p}$ value $=0,001$ ( $p$ value $<\alpha 0,05$ ) dan koefisien korelasi $(\rho)$ dengan nilai -0,50 yang dapat disimpulkan bahwa ada signifikansi dan bukan arah antara dukungan rawat inap tingkat kecemasan anak prasekolah. Dengan demikian, semakin baik rawat inap, semakin rendah tingkat kecemasan anak prasekolah. Diharapkan para profesional kesehatan untuk bekerja profesional untuk mencapai pelayanan optimal dan maksimal.
\end{abstract}

Kata Kunci: Rawat Inap, Tingkat Kecemasan, Anak Usia Prasekolah

\begin{abstract}
Sick children have a different response in which the child has unusual anxiety by interacting with other people, it causes the child must undergo hospitalization. In Indonesia an estimated 35\% of children undergoing hospitalization and $45 \%$ had anxiety. The purpose of this study was to determine the effect of hospitalization on the level of anxiety of preschool children in child inpatient hospital TK II Putri Hijau Kesdam I/BB city of Medan. This type of research is analytic survey with cross sectional design. The population in this study across Preschool children who were treated at the TK II Putri Hijau Kesdam I/BB Medan with the average monthly total of 35 patients. Samples used as many as 20 people using total sampling technique. The data were obtained using a questionnaire and analyzed by using Spearman Rank Test (Rho). The test results Spearman Rank (Rho) with the results obtained $\alpha=0.05 \mathrm{p}$ value $=0.001$ ( $\mathrm{p}$ value $<\alpha 0.05)$ and the correlation coefficient $(\rho)$ with a value of -0.502 which can be concluded that there are significant and not the direction being between hospitalization support the preschool child's anxiety level. Thus, the better the hospitalization, the lower the anxiety levels of preschool children. It is expected that health professionals in order to work professionalism to achieve optimum service and maximum.
\end{abstract}

Keywords: Hospitalization, Anxiety Levels, Preschool Children

\section{PENDAHULUAN}

Anak adalah individu yang masih memiliki ketergantungan pada orang dewasa dan lingkungan sekitarnya, anak memerlukan lingkungan yang dapat memfasilitasi dalam kebutuhan dasar serta belajar mandiri. Orang tua harus merawat anak dengan baik dan benar karena anak anugerah dari yang maha kuasa (Supartini, 2012).
Anak mulai belajar hidup mandiri semenjak usia Preschool dengan usia 3-6 tahun. Pada usia Preschool, anak belajar mengembangkan kemampuan dalam menyusun bahasa, berinteraksi dengan orang lain. Anak sakit mempunyai respon berbeda dimana anak mengalami kecemasan dengan tidak biasa berinteraksi dengan orang lain, hal ini menyebabkan anak harus menjalani hospitalisasi (Supartini, 2012). 
Penyakit dan hospitalisasi sering kali menjadi krisis pertama yang harus dihadapi anak, terutama selama tahun awal sangat rentan terhadap krisis penyakit dan hospitalisasi karena stress akibat perubahan dari keadaan sehat biasa dan rutinitas lingkungan. Kecemasan utama dari hospitalisasi antara lain adalah perpisahan, kehilangan kendali, cedera tubuh, dan nyeri (Wong, 2013).

Hospitalisasi merupakan proses dimana karena suatu alasan tertentu baik darurat atau berencana mengharuskan anak tinggal di rumah sakit menjalani terapi dan perawatan sampai pemulangan kembali ke rumah (Supartini, 2012).

Di Amerika Serikat, diperkirakan lebih dari 5 juta anak menjalani hosptalisasi karena prosedur pembedahan dan lebih dari $50 \%$ dari jumlah terebut, anak mengalami kecemasan dan stress (Kain dalam dilfera 2013). Menurut Smith (2004) dalam Weni Febriani Sari, 2014) hampir 4 juta anak di dunia dalam setahun mengalami hospitalisasi, $6 \%$ diantaranya berumur dibawah 7 tahun. Berdasarkan Survei Ekonomi Nasional (SUSENAS) Tahun 2010, jumlah anak usia Preschool di Indonesia sebesar $72 \%$ dari jumlah total penduduk Indonesia, dan diperkirakan 35\% anak menjalani hospitalisasi dan $45 \%$ diantaranya mengalami kecemasan. Respon kecemasan yang sering di alami anak seperti menangis dan takut pada orang yang baru dikenalnya (Sumaryoko dalam Weni, 2014). Hasil penelitian Purwandari tahun 2011 di RSUD Margono Soekardjo Purwokerto menunjukkan $25 \%$ anak usia preschool yang dirawat mengalami cemas tingkat berat, $50 \%$ tingkat sedang dan 20\% tingkat ringan. Anak menunjukkan respon menangis, memeluk ibunya, dan berteriak (Purwandari dalam lidia, 2013).

Berdasarkan survei awal yang peneliti lakukan di Rumah Sakit TK II Putri Hijau Medan pada bulan januari sampai oktober tahun 2014 diperoleh data 322 pasien anak preschool yang dirawat di ruang rawat inap anak.

Berdasarkan observasi yang peneliti lakukan di RS TK II Putri Hijau Kesdam I/BB Medan di Ruang rawat inap anak. Perawat masih jarang memperkenalkan anak kepada pasien lain yang berada di ruangan tersebut sehingga anak tidak nyaman berada di dalam ruangan tersebut, dalam melakukan tindakan perawat masih kurang mendekatkan diri kepada anak, sehingga pada saat dilakukan tindakan anak masih sering menangis.

Berdasarkan latar belakang diatas maka peneliti tertarik untuk melakukan penelitian dengan judul" Pengaruh Hospitalisasi Terhadap Tingkat Kecemasan Anak Preschool di Rumah Sakit TK II Putri Hijau Medan".

\section{METODE}

Desain penelitian yang digunakan adalah survey analitik yaitu penelitian yang mencoba menggali bagaimana dan mengapa fenomena kesehatan itu terjadi, kemudian melakukan analisis hubungan antar variabel. Dengan pendekatan cross sectional yang bertujuan untuk mengetahui pengaruh hospitalisasi terhadap tingkat kecemasan anak preschool di Rumah Sakit TK II Putri Hijau Kesdam I/BB Medan

Populasi penelitian ini adalah seluruh anak Preschool yg dirawat di Rumah Sakit TK II Putri Hijau Kesdam I/BB Medan. Dengan rata-rata perbulan sebanyak 35 pasien.

Teknik pengambilan sampel pada penelitian ini menggunakan teknik total sampling / sampel jenuh, yakni dengan mengambil seluruh anggota populasi menjadi sampel.

Variabel dalam penelitian ini terdiri dari variabel independen dan variabel Dependen. Variabel Independen dalam penelitian ini adalah Hospitalisasi dan Variabel Dependen adalah Kecemasan Anak.

\section{HASIL}

Tabel 4.1 Distribusi Frekuensi Responden

\begin{tabular}{cccc}
\hline No. & $\begin{array}{c}\text { Data } \\
\text { Demografi }\end{array}$ & Jumlah & Persentase \\
\hline 1. & Umur & & \\
6 Tahun & 12 & $34 \%$ \\
2. & 5 Tahun & 9 & $26 \%$ \\
3. & 4 Tahun & 8 & $23 \%$ \\
4. & 3 Tahun & 6 & $17 \%$ \\
\hline & Total & $\mathbf{3 5}$ & $\mathbf{1 0 0}$ \\
\hline
\end{tabular}




\begin{tabular}{|c|c|c|c|}
\hline \multicolumn{3}{|c|}{ Lama Rawat } & \multirow[b]{2}{*}{$60 \%$} \\
\hline 1. & 2-4 Hari & 21 & \\
\hline \multirow[t]{3}{*}{2.} & 5-7 Hari & 14 & $40 \%$ \\
\hline & Total & 35 & 100 \\
\hline & \multicolumn{2}{|l|}{ Nama Penyakit } & \\
\hline 1. & DBD & 12 & $34 \%$ \\
\hline 2. & Demam & 10 & $29 \%$ \\
\hline \multirow[t]{3}{*}{3.} & ISPA & 13 & $37 \%$ \\
\hline & Total & 35 & 100 \\
\hline & \multicolumn{2}{|l|}{ Pengobatan } & \\
\hline 1. & Berulang & 15 & $43 \%$ \\
\hline \multirow[t]{2}{*}{2.} & Tidak Berulang & 20 & $57 \%$ \\
\hline & Total & 35 & 100 \\
\hline
\end{tabular}

Hasil analisis pada tabel 4.1 diperoleh hasil bahwa sebagian besar responden berumur 6 tahun sebanyak 12 responden atau (34\%), dan sebagian kecil berumur 3 tahun sebanyak 6 responden atau $(17 \%)$. Berdasarkan lama rawat, diperoleh hasil bahwa sebagian besar responden dengan lama rawat 2-4 hari sebanyak 21 responden atau $(60 \%)$, dan sebagian kecil lama rawat 5-7 hari sebanyak 14 responden atau $(40 \%)$.

Berdasarkan nama penyakit, diperoleh hasil bahwa sebagian besar penyakit responden adalah ISPA sebanyak 13 responden atau $(37 \%)$, dan sebagian kecil Demam sebanyak 10 responden atau $(21,9 \%)$. Berdasarkan pengobatan, diperoleh hasil bahwa sebagian besar responden pengobatan tidak berulang sebanyak 15 responden atau $(43 \%)$, dan sebagian kecil berulang sebanyak 20 responden atau (57\%). Berdasarkan jawaban responden pada Tabel 4.2. di atas, maka hospitalisasi dapat dikelompokkan menjadi empat kategori yaitu selalu, sering, jarang, tidak pernah. Hasil penelitian menunjukkan bahwa hospitalisasi di Rumah Sakit TK II Putri Hijau Kesdam I/BB Medan adalah cukup yaitu sebanyak 24 orang $(65,6 \%)$. Seperti terlihat pada tabel 4.2. berikut ini:

Tabel 4.2 Distribusi Frekuensi Hospitalisasi

\begin{tabular}{lcc}
\hline \multicolumn{1}{c}{ Dukungan } & F & \% \\
\hline Baik & 6 & 17 \\
Cukup & 24 & 69 \\
Kurang & 5 & 14
\end{tabular}

\begin{tabular}{ccc}
\hline Total & 35 & 100 \\
\hline
\end{tabular}

Hasil penelitian menunjukkan bahwa tingkat kecemasan anak preschool di Rumah Sakit TK II Putri Hijau Kesdam I/BB Medan adalah sedang yaitu sebanyak 17 orang $(50 \%)$. Seperti terlihat pada tabel 4.3. berikut ini:

Tabel 4.3 Distribusi Frekuensi Tingkat Kecemasan Anak Preschool

\begin{tabular}{lcc}
\hline \multicolumn{1}{c}{ Dukungan } & F & \% \\
\hline Berat Sekali & 2 & 6 \\
Berat & 12 & 34 \\
Sedang & 17 & 49 \\
Ringan & 4 & 11 \\
\hline \multicolumn{1}{c}{ Total } & $\mathbf{3 5}$ & $\mathbf{1 0 0}$ \\
\hline
\end{tabular}

Analisa bivariat dalam penelitian ini bertujuan untuk melihat pengaruh variabel independen dan variabel dependen yaitu hospitalisasi terhadap tingkat kecemasan anak preschool di Ruang Rawat Inap Anak Rumah Sakit TK II Putri Hijau Kesdam I/BB Medan.

Tabel 4.4. Pengaruh Hospitalisasi terhadap Tingkat Kecemasan Anak Preschool di Ruang Rawat Inap Anak Rumah Sakit TK II Putri Hijau Kesdam I/BB Medan

\begin{tabular}{|c|c|c|c|c|c|c|c|c|}
\hline \multirow[b]{2}{*}{$\begin{array}{l}\text { Hospit } \\
\text { alisasi }\end{array}$} & \multicolumn{3}{|c|}{$\begin{array}{c}\text { Tingkat } \\
\text { Kecemasan }\end{array}$} & \multicolumn{3}{|c|}{ Total } & \multirow[b]{2}{*}{$\begin{array}{c}P \\
v a \\
l u \\
e\end{array}$} & \\
\hline & $\begin{array}{c}\text { B } \\
\text { er } \\
\text { at } \\
\text { Se } \\
\text { k } \\
\text { al } \\
\text { i }\end{array}$ & $\begin{array}{l}\text { B } \\
\text { er } \\
\text { at }\end{array}$ & $\begin{array}{l}\text { Rin } \\
\text { gan }\end{array}$ & $\begin{array}{c}\text { Se } \\
\mathbf{d} \\
\mathbf{a} \\
\mathbf{n} \\
\mathrm{g}\end{array}$ & $\mathbf{N}$ & $\%$ & & \\
\hline Baik & 0 & 0 & 2 & 4 & 6 & 17 & & - \\
\hline Cukup & 0 & 8 & 1 & 12 & 24 & 69 & 0 , & 0 \\
\hline Kurang & 2 & 3 & 0 & 0 & 5 & 14 & $\begin{array}{c}00 \\
\end{array}$ & 5 \\
\hline Total & 2 & 11 & 3 & 16 & 35 & $\begin{array}{c}10 \\
0\end{array}$ & & \\
\hline
\end{tabular}

Berdasarkan tabel 4.4. menggambarkan bahwa terdapat pengaruh yang bermakna antara hospitalisasi terhadap tingkat kecemasan anak preschool dengan nilai signifikansi (p) $0,001<0,05$ dan koefesien korelasi $(\rho)$ dengan nilai $-0,543$ yang berarti terdapat pengaruh yang sedang dan tidak searah antara dukungan 
hospitalisasi terhadap tingkat kecemasan anak preschool. Dengan demikian, semakin baik Hospitalisasi maka semakin rendah Tingkat Kecemasan Anak Preschool.

\section{Pembahasan}

\section{Hasil Hospitalisasi}

Hospitalisasi merupakan suatu proses yang karena suatu alasan yang berencana atau darurat, mengharuskan anak untuk tinggal di rumah sakit, menjalani terapi dan perawatan sampai pemulangannya kembali ke rumah. (Supartini, 2012).

Dari hasil penelitian menunjukkan bahwa sebagian besar hospitalisasi adalah kategori cukup yaitu sebanyak 24 orang (69\%). Hal ini menunjukkan bahwa hospitalisasi yang dilakukan adalah baik.

Menurut Supartini (2012), Anak usia preschool adalah anak yang berusia antara 3 sampai 6 tahun. Bagi anak usia preschool, sakit adalah sesuatu yang menakutkan. Selain itu perawatan di rumah sakit dapat meimbulkan cemas karena anak merasa kehilangan lingkungan yang dirasakannya aman, penuh kasih sayang, dan menyenangkan. Anak juga harus meninggalkan lingkungan rumah yang dikenalnya, permainan, dan teman sepermainannya.

Reaksi anak dan keluarganya terhadap sakit dan rumah sakit baik rawat inap ataupun rawat jalan adalah dalam bentuk kecemasan, stres, dan perubahan perilaku. Anak preschool lebih aman secara interpersonal daripada toddler maka mereka dapat menoleransi perpisahan singkat dengan orangtua mereka, akan tetapi stress karena penyakit biasanya membuat anak preschool menjadi kurang mampu menghadapi perpisahan, akibatnya mereka menunjukkan banyak tahap perilaku cemas akibat perpisahan seperti, menolak makan, mengalami susah tidur, menangis diamdiam,menarik diri dari orang lain, menolak bekerja sama selama proses perawatan (Wong, 2013).

Reaksi anak terhadap sakit dan rawat inap di rumah sakit berbeda-beda pada masing-masing individu. Hal tersebut dipengaruhi oleh beberapa faktor. Perkembangan usia anak merupakan salah satu faktor utama yang mempengaruhi reaksi anak terhadap sakit dan proses perawatan. (Supartini, 2012).

Sesuai dengan hasil penelitian yang menunjukkan bahwa sebagian besar responden berumur 6 tahun sebanyak 12 responden atau (34\%). Hal ini menunjjukan bahwa semakin tinggi usia anak maka reaksi terhadap semakin baik.

Selain itu, pengalaman anak sebelumnya terhadap proses sakit dan dirawat juga sangat berpengaruh. Apabila anak pernah mengalami pengalaman tidak menyenangkan selama di rumah sakit sebelumnya akan menyebabkan anak trauma dan takut. Sebaiknya jika anak mendapatkan perawatan baik dan menyenangkan anak akan lebih kooperatif pada perawat atau dokter (Supartini, 2012).

Sistem pendukung yang tersedia akan membantu anak beradaptasi dengan lingkungan rumah sakit dimana dirawat. Anak akan mencari dukungan yang ada dari orang terdekat seperti saudara atau orangtua untuk melepaskan tekanan akibat penyakit yang dideritanya. Perilaku ini biasanya ditandai dengan permintaan anak untuk ditunggui selama perawatan di rumah sakit, Didampingi saat pengobatan (Supartini, 2012).

\section{Hasil Tingkat Kecemasan Anak Preschool}

Kecemasan (Ansietas) adalah gangguan alam perasaan yang ditandai dengan perasaan ketakutan atau kekhawatiran yang mendalam dan berkelanjutan, Kepribadian masih tetap utuh (tidak mengalami keretakan kepribadian) (Hawari, 2013).

Dari hasil penelitian menunjukkan bahwa sebagian besar tingkat kecemasan anak adalah kategori sedang yaitu sebanyak 16 orang (46\%). Hal ini menunjukkan bahwa tingkat kecemasan yang dialami anak usia presekolah selama menjalani perawatan di rumah sakit termasuk dalam kategori cemas sedang.

Wong (2013) menyatakan bahwa hospitalisasi pada anak seringkali menyebabkan munculnya stressor-stressor yang dapat mengganggu perkembangan anak. Kemampuan koping anak tersebut dipengaruhi oleh beberapa faktor. Faktorfaktor tersebut menurut Wong adalah tingkat 
perkembangan umur, pengalaman sakit sebelumnya, perpisahan atau hospitalisasi, terdapatnya support system atau dukungan dari lingkungan sekitar, keahlian koping alami ataupun yang di dapat dan keseriusan diagnosa penyakit.

Menurut Carson anak-anak akan bereaksi terhadap stressor-stressor yang ditimbulkan oleh karena hospitalisasi baik pada saat masuk untuk pertama kali, selama proses hospitalisasi, dan nantinya setelah keluar dari rumah sakit. Namun demikian gambaran anak pada saat sebelum hospitalisasi mengenai keadaan sakitnya lebih penting daripada usia maupun kematangan intelektualnya dalam mempengaruhi tingkat penyesuaian diri anak selama hospitalisasi (Wong, 2013).

\subsubsection{Pengaruh Hospitalisasi terhadap Tingkat Kecemasan Anak Preschool di Ruang Rawat Inap Anak Rumah Sakit TK II Putri Hijau Kesdam I/BB Medan}

Berdasarkan Tabel 5, hasil korelasi
antara hospitalisasi terhadap tingkat kecemasan anak preschool dengan menggunakan uji korelasi Spearman Rho didapatkan hasil nilai $(\rho)=-0,543$ dengan nilai signifikan sebesar 0,001 . Menurut Sugiono (2006) dari hasil tersebut mempunyai arti bahwa terdapat korelasi antara hospitalisasi terhadap tingkat kecemasan anak preschool. Koefisien korelasi $(\rho)$ memberikan hasil negatif, hal ini berarti bahwa adanya pengaruh terbalik antara hospitalisasi terhadap tingkat kecemasan anak preschool yang menunjukkan semakin baik hospitalisasi yang diberikan semakin rendah tingkat kecemasan yang dialami oleh anak usia prasekolah. Sehingga hipotesis penelitian ini diterima yaitu ada pengaruh antara hospitalisasi terhadap tingkat kecemasan anak preschool. Nilai korelasi sebanyak 0,543 menunjukkan bahwa korelasi antara hospitalisasi terhadap tingkat kecemasan anak preschool mempunyai nilai sedang (Sugiono, 2017).

Proses hospitalisasi pada usia anak Preschool menunjukkan kecemasan akibat perpisahan dengan cara menolak makan, mengalami sulit tidur, menangis diam-diam karena kepergian orang tua mereka, terus bertanya kapan orangtua mereka datang, atau menarik diri dari orang lain. Mereka dapat mengungkapkan rasa marah secara tidak langsung dengan memecahkan mainan, memukul anak lain, atau menolak bekerja sama selama aktivitas perawatan diri yang biasa dilakukan. Perawat perlu sensitif terhadap tanda-tanda cemas akibat perpisahan yang kurang nyata tersebut agar dapat memberikan intervensi dengan tepat (Wong, 2013).

Dari literatur dan hasil penelitian yang ditemui, peneliti berasumsi bahwa ada pengaruh hospitalisasi terhadap tingkat Kecemasan anak preschool di ruang rawat inap anak Rumah Sakit TK II Putri Hijau Kesdam I/BB Medan. Hal tersebut terjadi karena hospitalisasi yang baik dilakukan pada anak preschool membuat tingkat kecemasan pada anak semakin berkurang.

\section{Kesimpulan}

Dari hasil penelitian ini didapatkan bahwa bahwa sebagian besar hospitalisasi adalah kategori cukup yaitu sebanyak 24 orang $(69 \%)$.

Dari 35 responden diperoleh tingkat kecemasan anak preschool menunjukkan bahwa sebagian besar tingkat kecemasan anak adalah kategori sedang yaitu sebanyak 17 orang (49\%).

Dimana nilai koefisien korelasi yang didapat pengaruh hospitalisasi terhadap tingkat kecemasan anak preschool adalah sebesar $-0,502$ dengan $p \quad$ Value $<\alpha$ $(0,001<0,05)$ dengan taraf signifikansi $5 \%$ sehingga dapat disimpulkan bahwa terdapat Pengaruh Hospitalisasi terhadap Tingkat Kecemasan Anak Preschool di Ruang Rawat Inap Anak Rumah Sakit TK II Putri Hijau Kesdam I/BB Medan.

\section{Saran}

Bagi Institusi Pendidikan

Diharapkan kepada Institusi

Pendidikan untuk menambah ilmu pengetahuan mahasiswa diinstitusi mengenai hospitalisasi.

Bagi Tenaga Kesehatan

kesehatan agar bekerja secara 
profesionalisme untuk mencapai pelayanan yang optimal dan maksimal.

Bagi Peneliti Lain

Hasil penelitian ini dapat dijadikan referensi untuk melakukan penelitian sejenis dengan sampel yang lebih banyak atau dengan faktor faktor lain yang lebih baik lagi

\section{DAFTAR PUSTAKA}

Dilfera dan Zadam. 2013. Pengaruh terapi bermain dengan tingkat kecemasan anak. http://jurnal.umsb.ac.id. Diakses: 4 desember 2014.

Hidayat. 2010. Metode Penelitian Kesehatan: Paradigma Kuantitatif. Jakarta: Health Book Publishing

Hawari, Dadang. 2011. Manajemen stress, cemas dan depresi. FKUI, Jakarta.

Kain dalam Difera. 2013. Hubungan support system keluarga dengan tingkat kecemasan anak. http://Stikesdehasen.ac.id. Diakses: 4 desember 2014
Nursalam. 2013. Metode Penelitian ilmu keperawatan. Jakarta: Salemba Medika.

Purwandari dalam lidia. 2013. Hubungan Perilaku Caring Perawat Terhadap Stres Hospitalisasi http://ejournal. Stikes Sam Ratulangi.wordpress.com

Weni. 2014. Pengaruh terapi bermain terhadap penurunan kecemasan anak. http://ejournal.unsrat.ac.id. Diakses: 4 desember 2014.

Supartini,Yupi. 2012. Konsep Dasar keperawatan Anak. Jakarta: EGC.

Sugiono. 2017. Metode Penelitian Kuantitatif, Kualitatif. Bandung: Alfabeta.

Suzana. 2005. Metode Statistika. Bandung: Tarsito

Wong. L. Donna. (2013). Buku Ajar Keperawatan Pediatrik. Jakarta: EGC 